\title{
What Did the European Community Founders Actually Mean by Saying That the Treaties Shall in No Way Prejudice the Rules in Member States Governing the System of Property Ownership? Analysis of Article 345 TFEU $^{1}$
}

I am grateful for yet another invitation to speak at a Polish-Russian conference in Obrzycko. I would like to use this opportunity, in connection with the subject of the present conference - which is ownership - to discuss Article 345 of the Treaty on the Functioning of the European Union (Hereinafter: TFEU or Treaty). This is the sole provision referring to the subject of ownership in general terms (not intellectual property or immovable property) in the whole Treaty. Yet it is very ambiguous, and its ambiguity creates many normative puzzles and also enhances the picture of Community/Union law as lacking clear and precise reference to the private laws of its Member States.

\section{General comments}

The historical context of the adoption of Article 345 of TFEU is quite useful in understanding the role of this provision in the TFEU structure. The social and political environment in which EU law is currently applied has undergone significant changes in comparison to how the situation was in the middle of the 1950s. In particular, the currently prevailing opinion in Europe is that private ownership is superior in comparison to state (public) ownership. The public debate has shifted more to the issue of fund distribution, leaving the problems of the ownership of the means of production aside. In consequence, one may dare to offer the conclusion that the role set by the drafters of Article 83 of the ECSC Treaty was slightly different from the role this provision plays today. Given the judicial practice of the Court presented below, it seems that Article 345

1 In preparing this article I have relied to the large extent on my previous publication: Komentarz do artykutu 345 [in:] Traktat o Funkcjonowaniu Unii Europejskiej, red. A. Wróbel, D. KornobisRomanowska, J. Łacny, t. III, Warszawa 2012, p. 1072-1082. 
cannot be assigned any normative importance, as a certain type of treaty super-derogation. It is the Court's well-established opinion that this provision does not exempt public enterprises from the scope of the application of particular provisions of the Treaty (Article 34, 63,102,106,110). Public and private entities, according to the Court of Justice of the European Union (Hereinafter: the Court or ECJ), are to be treated in an equal manner.

However, the thesis on the fundamental importance of this provision does not withstand the test of a review of the Court's judicial practice. In the majority of cases examined by the Court, parties relied on Article 345 rather in terms of a defensive argument, which was usually rejected anyway. This was the case, inter alia, in actions aiming to declare the Commission's decisions on competition law as invalid ${ }^{2}$, actions concerning state aid $^{3}$, actions aiming to repeal directives or regulations ${ }^{4}$ or in actions brought by the Commission on the grounds of Article 2585. Sometimes the Court does not refer to the charge of violation of Article 345 at all .

However, Article 345 may play a certain normative role if a strictly linguistic interpretation is applied - as a provision leaving the exclusive competence to determine the area of ownership rights in the sense of private law regulations to particular member states, especially during the debate on the integration of private law, or, even more so, introduction of a European Civil Code.

\section{Evolution}

Article 345 is based directly on the text of Schumann's declaration. The relevant fragment from the speech by the French Minister of Foreign Affairs of 9 May 1950 reads: The institution of the High Authority will in no way prejudge the methods of ownership of enterprises (Fr. L'institution de la Haute Autorité ne préjuge en rien du régime de propriété

2 T-196/04 Ryanair, item 65.

3 C-457/00 the Republic of Belgium vs. Commission, item 44; C-66/02 The Republic of Italy vs. Commission, item 128; combined cases T-228/99 and T-233/99 Westdeutsche Landesbank Girozentrale and Land Nordrbein-Westfalen vs. Commission, item 194-198 and 234-274; C-482/99 The Republic of France vs. Commission, items 26 and 30 - in the last two cases the Court agreed with the reservations submitted by the plaintiffs and repealed the decisions; combined cases C-442/03 P and C-471/03 P PEO European Ferries (Vizcaya) SA and Diputación Foral de Vizcaya vs. Commission, items 20 and 30; the opinion of advocate general Tizzano of 9 February 2006 in combined cases C-442/03 P and C-471/03 PङO European Ferries (Vizcaya) $S A$ and Diputación Foral de Vizcaya vs. Commission.

4 E.g. the directive restricting marketing activities for tobacco products, see C-491/01 British American Tobbaco, items 143 and 146-148 or the regulation on a European cooperative, see the opinion of the Advocate General Stix-Hackl to C-436/03 PE vs. Council, items 69 and 70.

5 C-503/04 Commission vs. Germany, items 31 and 37.

6 C-97/98 Peter Jägerskiöld vs. Torolf Gustafsson, item 12. 
des entreprises). A rule worded in a similar way was included in Article 83 of the ECSC Treaty (The establishment of the Community shall in no way prejudice the system of ownership of the undertakings to which this treaty applies). One should remember that, at the beginning of the 1950s, state owned companies in the coal and steel industries were as common as privately owned ones. For instance, France nationalised its coal industry shortly after the end of World War II. Equally, state-owned companies were in the majority in Italy. Article 83 of the ECSC Treaty was to legitimise this status ${ }^{7}$. As shown by the preparatory documents, this rule was supposed to be worded in the same way in the EEC Treaty. According to the version submitted to the committee drafting the Treaty, this provision was to be worded in the following way: The institution of the High Authority will in no way prejudge the methods of ownership of the means of production in the Community (Fr. Le présent Traité ne préjuge en rien le régime de propriété des moyens de production existant dans la Communauté). One may wonder whether the use of the Marxist category of the means of production in the draft, disregarding at the same time the specification of the form of ownership of enterprises, was not designed to solicit the support of socialist political movements in the parliaments of the states negotiating the treaty, as they were sceptical about the idea of European integration ${ }^{8}$. There are opinions in the literature that the purpose of Article 345 was to leave the freedom to nationalise certain sectors of the economy to member states ${ }^{9}$. Only in the final version of the treaty submitted to the Committee of the Delegation Leaders on 6 March 1957 did the reference to the ownership of enterprises (the means of production) disappear ${ }^{10}$. It has been indicated that this was due to a broadening in the scope of the regulations of the EC Treaty, which did not refer exclusively to enterprises ${ }^{11}$.

As a result of the coming into force of TL, Article 345 was amended only slightly, i.e. the plural form was introduced (The Treaties shall in no way prejudice instead of The Treaty shall in no way prejudice used in the previous version), which is an extension of the effective power of the provision to the two treaties in force. The remaining part of the provision remained unchanged.

7 P. Herzog et. al., The Law of the European Economic Community. A Commentary on the EEC Treaty, New York 1981, p. 6-167.

8 For more on the Marxist theory of ownership, v. M. Bednarek, Przemiany wtasności w Polsce, Warszawa 1994, p. 13, and, most importantly, K. Marx, Kapitat, Warszawa 1959, p. 368-369.

9 P. Herzog et. al., op. cit., p. 6-164.

10 S. Neri, H. Sperl, Traité instituant la CEE, Travaux préparatoires, Luxembourg 1960, p. 410.

$11 \mathrm{~V}$. the opinion of the advocate general Ruiz-Jarabo Colomer C-367/98 Commission vs. the Republic of Portugal; C-503/99, Commission v. the Kingdom of Belgium and C-483/99 the Commission vs. the Republic of France, items 45-51. 


\section{The nature of the provision}

No direct effect. As shown by the judicial practice of the Court of Justice, Article 345 is usually relied on by member states, which treat this provision as a derogation from particular treaty norms (e.g. Article 63 or Article 102). Private entities rely on Article 345 only in exceptional cases (see the case T-362/04 Mnin). Assuming that the direct effect of European law norms means that they may be an independent source of rights and obligations for entities (natural and legal persons) ${ }^{12}$, one should conclude that Article 345 does not have a direct effect. This is a consequence of the fact that Article 345 will never be applied independently. Its very nature determines its function as that of a meta-norm, outlining the limits of the applicability of EU norms. At the same time, we may come across a situation where an entity relies on Article 345 to prevent the application of EU norms to itself, beyond the scope reserved to the member states under Article 345. In this sense, Article 345 may be the source of the entity's right to request that an EU norm imposing obligations or restricting its rights is not applied to it. This situation though, may not be referred to as a direct effect of Article 345.

\section{Systemic context}

Article 345 is found in the seventh part of the TFEU (previously the sixth part of the TEC) entitled General and final provisions. In his opinion, the Advocate General RuizJarabo Colomer points out that both the placement of the provision (in a footnote the advocate clearly speaks of - wording it in an arithmetical manner - exclusion before the brackets) and its unconditional tone (expressed by using 'in no way') determine its basic significance ${ }^{13}$.

In the literature it is assumed that the rules regarding ownership rights in the scope covered by the Treaty should be construed as all significant elements of ownership-related rights in the constitutional sense. Therefore, they include both provisions governing private ownership, expropriation or other forms of the socialisation of assets, and provisions setting limits for the use of ownership. Nationalisation, as a rule, is treated as an internal issue for every state. However, any nationalisation which would undermine the very foundations of the market economy in a specific state is considered inadmissible ${ }^{14}$.

12 S. Biernat, J. Barcz et. al., Prawo Unii Europejskiej. Zagadnienia systemowe, Warszawa 2002, p. 242.

13 The opinion of the Advocate General Ruiz-Jarabo Colomer of 3 July 2001 to the case C-367/98 Commission vs. the Republic of Portugal; C-503/99 Commission vs. the Kingdom of Belgium and C-483/99 the Commission vs. the Republic of France, item 45 et seq.

14 B. Kordasiewicz, M. Bednarek, Polskie prawo obrotu gruntami na tle standardów europejskich i postanowień wiążacych Polskę umów międzynarodowych (raport końcowy), Studia Prawnicze vol. 
It is claimed that due to the exceptionally vast scope of the application of this provision, its linguistic interpretation is not sufficient: the concept of ownership is used here not only in a legal, but, above all, in an economic context ${ }^{15}$.

\section{The application of Article 345 to special objects of ownership rights}

\subsection{Intellectual Property}

The authors of Article 345 probably intended to ensure the neutrality of EU law with respect to forms of ownership, especially as far as enterprises are concerned. Meanwhile, this provision has played an important role in the dispute concerning the scope of the execution of exclusive rights under patents, trademarks and other intangible assets. An example of the application of this provision in this context is the case 24/67 Parke, Davis E Co. p. Pröbel et al., concerning a Dutch patent for the production of an antibiotic called Chloramphenicol, owned by an American company, Parke, Davis \& Co. Due to the lack of patent protection for pharmaceuticals in Italy in 1960s, Pröbel manufactured and marketed Chloramphenicol in this country without Parke, Davis \& Co.'s consent. In collaboration with other companies, it also attempted to sell the medicine produced in Italy in the Netherlands, also without Parke, Davis \& Co.'s consent. The latter company submitted a claim requesting that the violation of its exclusive rights be discontinued, while Pröbel defended itself by claiming that the actions of the patent owner violate the freedom of movement of goods and form an abuse of the entity's dominant position. The Court - taking into account the nature of the ownership right under the ex Article 295 and current Article 345, including exclusive rights under patent (and this is the provision the advocate general Römer explicitly referred to) - found that the entity entitled to rights under the patent could exercise its rights in order to object to the import of protected goods from another state where such patent protection was unavailable and that such an action does not violate the freedom of movements of goods or an abuse of the dominant position in the meaning of Article 10216. The ex Article 295 and current Article 345 were also relied on in many other cases, e.g. 78/70 Deutsche Grammophon vs. Metro-SB-Grossmarkt or 15/74 and 16/74 Centrafarm BV et al. vs. Sterling Drug Inc. (in reference to compulsory licenses, see C-235/89 Commission vs. The Republic of Italy; C-30/90 Commission vs. the United Kingdom). In these cases we can observe a certain shift of focus. Namely, the Court found that the ex Article 295 and the current Arti-

1,1996, p. 245; P. Herzog et. al., op. cit., p. 6-174.

15 J. Thiesing, H. Groeben, J. Thiesing, C.-D. Ehlermann et. al., Kommentar zum EWG-Vertrag, Baden-Baden 1983, notes to Article 222.

16 L. Giliciński, Wykonywanie praw wtasności intelektualnej w prawie Wspólnoty Europejskiej, Warszawa 1997, p. 36. 
cle 345 cannot be construed as granting the local legislator the competence to adopt legal measures which could violate the free flow of goods in the common market in the way stipulated by the Treaty in reference to industrial property. The ECJ adjudicated likewise in the case C-350/92 Spain vs. the Council ${ }^{17}$ To sum up, given the currently binding law, the Court assumes that Article 345 does not exempt the issue of exercising exclusive rights in the area of intellectual property from the scope of application of EU law.

\subsection{Mandatory re-organisation of state monopolies (relationship between Article 345 and Article 37)}

Article 37 obliges the member states to reorganise their state monopolies, in order to ensure that there is no discrimination between the citizens of member states with respect to the procurement and marketing of goods (see the commentary on Article 37). The relationship between the ex Article 295, currently Article 345 and ex Article 31, currently Article 37, was commented on by the Advocate General Léger in his opinion. It is his belief that Article 37 in conjunction with Article 345 cannot be interpreted as an obligation, introduced by the Treaty, to liquidate entities holding exclusive rights. Nevertheless, the obligation to adjust state monopolies operating in the area of trade in a way which ensures a lack of discrimination between the citizens of members states with respect to the procurement and marketing of goods, which results from Article 37, may lead to the order of waiving certain exclusive rights. Examples from the Court's judicial practice include the exclusive import or export rights to particular goods ${ }^{18}$. In the case C-438/02, the Court found the state monopoly of certain entities for the retail trade in pharmaceuticals in Sweden incompliant with Article 37.

\subsection{Golden shares (relationship between Article 345 and Article 63)}

On 4th June, 2002, and 13th May, 2003, the ECJ issued five judgements in cases instituted on the basis of actions brought by the Commission vs. the Republic of Portugal (C-367/98), the Kingdom of Belgium (C-503/99), the Republic of France (C-483/99), the Kingdom of Spain (C-463/00) and the United Kingdom (C-98/01) All of them pertained to the issue of golden shares. Despite having conducted privatisation processes, many European states retained control of the companies created as a result of the privatisation of state enterprises. At the end of the 1990s, the Commission decided to institute proceedings against some member states, putting forward a charge that the scope of the rights such states enjoy in companies created as a result of the privatisation of state enterprises violates the rule of the free flow of capital. The factual circumstances in all five cases boiled down to the following issue: the internal laws granted special compe-

17 In reference to the prohibition of discrimination v. C-92/92 and C-326/92 Phil Collins.

$18 \mathrm{~V}$. the opinion of the advocate general Léger to the case C-438/02 Åklagaren vs. Krister Tanner, item 41. 
tences within the privatised enterprises to public authorities. Such competences usually involved the right to veto selected decisions made by the company authorities or the retained right to appoint a specified number of members of the company authorities. According to the Commission, maintaining such rights hinders investments in privatised enterprises, thereby discouraging investors from other member states from investing their funds, and, in consequence, makes the free flow of capital illusionary. In their defences, the member states pointed out that the restrictions of freedoms which could result from adopting the disputed provisions were justified by the necessity of ensuring public safety and the over-riding requirements of public interest, stipulated by Article 65(1), which involve, inter alia, ensuring uninterrupted supplies of energy. According to such states, the measures which had been adopted were proportional and sufficient to attain the intended objective. Moreover, the states relied on the rule of neutrality with respect to the ownership system in the member states, stipulated by ex Article 295 and current Article $345^{19}$. The Advocate General, Ruis-Jarabo Colomer, agreed with this argumentation in his opinions for the cases Commission vs. the Republic of Portugal (C-367/98), the Kingdom of Belgium (C-503/99), the Republic of France (C-483/99), the Kingdom of Spain (C-463/00) and the United Kingdom (C-98/01). The Advocate General pointed out that the regulation of ex Article 295 and current 345 ensures the neutrality of EU law with respect to the ownership of enterprises construed in the economic sense as the means of production. He found that the golden share rules in force in such member states should be considered compliant with community law, specifically on the grounds of ex Article 296 and current Article 345. Since, if a member state may, in compliance with the Treaty, decide to privatise state enterprises, one should assume - by consistent application of the rule who may do more may also do less - that the state may also equip its administration bodies with special competences concerning a privatised enterprise ${ }^{20}$.

In all five cases the Court found that the provisions of the member states challenged by the Commission constituted restrictions to the freedom of capital flow since they hindered its execution, thereby discouraging investors from other member states from investing their funds and making the freedom of capital flow illusory. According to the ECJ, there is no doubt that the goal of the provisions challenged in the aforementioned cases, i.e. securing the supply of energy in case of a crisis, should be classified as a goal justified by the public interest. However, the Court emphasised that the requirements of the public interest, being an exception to the fundamental rule of the freedom of capital flows, must be interpreted in a strict manner so that their scope could not be determined unilaterally by a member state without any control on the part of the community insti-

19 C-465/00 Commission vs. the Kingdom of Spain, item 41.

20 The opinion of the advocate general Ruiz-Jarabo Colomer to cases C-367/98 Commission vs. the Republic of Portugal; C-503/99, Commission v. the Kingdom of Belgium and C-483/99 the Commission vs. the Republic of France, item 45. 
tutions. Public interest requirements may be relied on only if an actual and sufficiently serious threat to a basic social interest is at stake. Consequently, in the Court's opinion, it was necessary to examine whether the measures adopted by a member state allow for ensuring the minimum supplies of energy in the case of an actual and serious threat and whether they do not go beyond what is necessary to attain this goal. As a result of the analysis performed, the Court found that only the Belgian provisions correspond to these requirements.

As far as the argumentation based on the neutrality of the Treaty with respect to forms of ownership is concerned, member states are not allowed - in the Court's opinion - to rely on the rules concerning ownership rights which are in force in member states in order to justify hindrances in exercising the freedoms guaranteed by the Treaty, caused by granting excessive privileges to the state as a shareholder of privatised enterprises ${ }^{21}$.

\subsection{Real estate (relationship between Article 345 and Article 63)}

In the case 182/83 Fearon vs. Irish Land Commission, the Court found that despite the fact that pursuant to ex Article 296, currently Article 345, the rules of law governing ownership rights have been reserved to the exclusive competence of member states, this provision does not exempt such rights from the effective scope of the basic Treaty rules ${ }^{22}$. This thesis was reiterated in the case C-302/97 Klaus Konle vs. the Republic of Austria. The reference for a preliminary ruling submitted by the Austrian court referred to the scope of restrictions applicable to real estate transactions admissible under ex Article 56, currently Article 63 of the Treaty. Pursuant to Article 9(1a) and Article 12(1) of the Austrian act on the transfer of land in Tyrol of 1996, a buyer of real estate located in Tyrol must obtain a relevant permit. The permit is granted on condition of proving that the purchased real estate will not be used as a so-called secondary residence ${ }^{23}$. This restriction was a consequence of the Austrian government's policy aimed at ensuring that Tyrol would be inhabited by a stable population running businesses in other sectors, independent from tourism. Klaus Konle, a citizen of Germany, bought a plot in Tyrol and intended to move there, but a competent administrative authority refused to grant him a permit. Konle appealed to a higher authority and, as a consequence of subsequent proceedings, the

21 C-483/99 Commission vs. the Republic of France, item 44; C-503/99 Commission vs. the Kingdom of Belgium, item 44; C-463/00 Commission vs. the Kingdom of Spain, item 41; likewise C-174/04 Commission vs. the Republic of Italy; the opinion of Advocate General Kokott to C-174/04 Commission vs. the Republic of Italy, item 24 and 47; C-326/07 Commission vs. the Republic of Italy; the opinion of Advocate General Colomer to C-326/07 Commission vs. the Republic of Italy, item 6 and 35-42. From more recent cases: the judgement issued in the case C-171/08 Commission vs. the Republic of Portugal and the judgement issued in the case C-543/08 Commission vs. the Republic of Portugal.

22 182/83 Fearon vs. Irish Land Commission, item 7.

23 C-302/97 Klaus Konle vs. the Republic of Austria, item 11. 
Regional Civil Court (Landesgericht) in Vienna referred to the Court for the preliminary ruling. In its judgement the Court found that despite the fact that pursuant to ex Article 295 , currently Article 345 , the rules governing ownership rights have been reserved to the exclusive competence of the member states, this provision does not exempt such rights from the effective scope of the basic Treaty rules. Thereby the Tribunal presented its position in response to the stance of the governments of Greece and Austria, willing to exempt the issue of granting permits for the acquisition of real estate by administrative authorities of particular member states from the jurisdiction of the Court (items 37 and 38). The Tribunal found that the Austrian act violates the freedom of capital movement. A similar position was presented in the combined cases C-515/99, C-519/99 to C-524/99 and C-26/99 to C-540/99 Reisch et al (items 28-31) and C-300/01 Salzmann (item 39); C-213/04 Ewald Burtscher and C-452/01 Ospelt (item 24).

In the case 309/96 Annibaldi vs. Sindaco del Comune di Guidonia and Presidente Regione Lazio, the Court examined Italian provisions introducing restrictions of ownership rights due to the establishment of a landscape and archaeological park. It found that these issues, in view of Article 345, are reserved to the competence of member states due to the lack of detailed provisions of the community law on expropriation, and taking account of the fact that the provisions establishing common organization of agricultural markets do not govern the issues of agricultural property ownership (item 23).

\subsection{The abuse of a dominant position (relationship between Article 345 and Article 102)}

The case 41/83 the Republic of Italy vs. Commission referred to the Commission's decision declaring that the British state telecom company had abused its dominant position. The plaintiff claimed that ex Article 295, currently Article 345, allows for the establishment of state monopolies, thereby exempting them from the application of ex Article 82, current Article 102. Moreover, relying on ex Article 295, currently Article 345, Italy found that the operation of a public enterprise cannot be examined from the perspective of ex Article 82, currently Article 102 (items 13 and 21). The Tribunal dismissed the case, since it did not consider the activity the case pertained to as a state monopoly. However, one should note that in the grounds to the judgement, the Tribunal did not reject expressis verbis the opinion presented by Italy as to the relationship between Article 345 and Article 102.

In the case C-163/99 the Republic of Portugal vs. the Commission, while examining the action submitted by Portugal against the decision of the Commission prohibiting certain methods of setting airport charges by the company managing airports as incompliant with ex Article 82, currently Article 201 and ex Article 86(1), currently Article 106(1), the Court explicitly found that Article 102, referring to the abuse of a dominant position, is applicable to all entrepreneurs enjoying a dominant position, regardless of 
whether they are privately or state-owned. Therefore, Article 345 does not preclude the application of Article 102 in relation to public enterprises (in this respect see also e.g. C-92/92 and C-326/92 Phil Collins). As far as more recent opinions are concerned, see the opinion of the Advocate General Mazák on the case C-52/09 Konkurrensverket vs. TeilaSonera $A B$ (item 27).

\subsection{Enterprises enjoying special or exclusive rights (relationship between Article 345 and Article 106)}

The Advocate General Rieschl, in his opinion referring to the combined cases 188/80190/80 the Republic of France, the Republic of Italy and the United Kingdom vs. Commission, found that ex Article 295, currently Article 345, imposes restrictions on the Commission's rights under ex Article 86(1), currently Article 106(3) to exercise influence on the internal structure of public enterprises. He also found that the freedom of public authorities to partake in business cannot be restricted to a broader extent than stipulated by the Treaty.

What is more, the Advocate General Tesauro in his opinion on the case C-202/88 the Republic of France vs. Commission also found that the direct relationship between currently binding provisions of Article 345 and 106 shows that there is at least a strong presumption that the existence of state enterprises and holders of exclusive rights is compliant with EU law.

\subsection{State aid}

In the case C-305/89 the Republic of Italy vs. Commission on state aid involving financial support for the automotive sector, the plaintiff claimed that the classification of support as state aid on the sole basis of the fact that public funds are involved is a violation of ex Article 295, currently Article 345 (item 17). The Court did not agree with this opinion and found that the Commission had correctly applied the Treaty, treating private and public enterprise owners alike (item 24).

In the combined cases C-83/01, C-93/01 and C-94/01 Chronopost S.A., La Poste and the Republic of France vs. Ufes et al., the Court found that the requirement of the arm's length remuneration payable to a monopolist state enterprise in exchange for services provided to its subsidiary does not prevent such an enterprise from accessing the market. This obligation results only in submitting such an enterprise to the rules of competition and does not violate the system of state ownership of enterprises - it only ensures that the state and public entities are treated alike.

In the case T-114/00 Aktionsgemeinschaft Recht und Eigentum eV vs. Commission the Court found that the German provisions governing the transfer of farmland and forested land in the area of the former German Democratic Republic are subject to assessment from the perspective of their compliance with the Treaty regulations on state aid, 
and, consequently, one cannot effectively rely on the exclusive competence of a member state under Article 345 in this respect (items 29 and 62).

\section{European Union sanctions (relationship between Article 345 and Article 215)}

In the case T-362/04 Mnin the Court referred to the charge that the freezing of assets under regulation 872/2004 on further restrictive measures applicable to Liberia, adopted under Article 75 in conjunction with Article 215 (ex Article 60 in conjunction with Article 301 TEC), violates ownership rights, including the violation of ex Article 295, currently Article 345 (item 77). The Court found that even if a specific legal measure violates ownership rights, it is not precluded under Article 345, provided that other provisions of the Treaty explicitly grant the Community (currently - the Union) the competence to perform such actions. In this case, the Court relied on Article 75 in conjunction with Article 215, used as a basis for issuing the above-mentioned regulation ${ }^{24}$.

\section{Summary}

The title of this article was: What did the European Community Founders actually mean by saying that the Treaties shall in no way prejudice the rules in Member States governing the system of property ownership? I hope that my brief historical analysis will convince readers that their intention was to persuade the polities of Member Statesto be that European integration does not equate to nationalization of their industry. Therefore, it was initially intended more as a political declaration, rather than a regulatory provision. But articles in legal texts have a life of their own, and especially such a meaningful provision in such an important text as the Treaty. I intended to show that in contemporary readings, Article 345 is raised mainly as a Member State's defense against (perceived) overreaching of Union bodies or Union law. Mostly a failed defense, it has to be said. So maybe the understanding of this Article in fact did not wander far from its original destination. It was conceived as a safeguard for a Member State's autonomy (with respect to ownership of enterprises) and continues to be used that way, albeit with limited success.

24 T-306/01 Yusuf, item 299 and C-415/05 Kadi and Al Bakarat International Foundation vs. the Council and Commission. 
50 | Adam Mickiewicz University Law Review

\section{Biographical reference:}

Maciej Mataczyński - is an Adam Mickiewicz University professor of law and advocate specializing in EU law, company \& capital markets law and private international law. Educated in Poznan, The Hague and Harvard. His recent publications include a monograph on major stockholders' obligations and a series of articles on law applicable to companies. He lives in Poznan.

SUMMARY

What did the European Community founders actually mean by saying that the treaties shall in no way prejudice the rules in member states governing the system of property ownership?

The study aims at an analysis of the Article 345 of the Treaty on the Functioning of the European Union. The author presents the relation between European Union law and the member state law regulating property ownership. The author makes an attempt to answer what did the European Community founders actually mean by saying that the treaties shall in no way prejudice the rules in member states governing the system of property ownership.

KEYwords: property ownership, TFUE, European Union law, civil law 